\title{
KOMUNIKASI PEMERINTAHAN ANTAR PERANGKAT DAERAH DI PROVINSI NUSA TENGGARA TIMUR (NTT)
}

\author{
Yohanes Museng Ola Buluamang1, Leope Pinnega Handika² \\ ${ }^{1,2}$ Badan Penelitian dan Pengembangan Daerah Provinsi Nusa Tenggara Timur \\ Jl. Basuki Rachmat No. 1, Naikolan, Kota Kupang, Nusa Tenggara Timur, 85111, Indonesia \\ No. Telp/Hp: ${ }^{10} 085293409894,{ }^{2} 081234406224$ \\ E-mail: ${ }^{1}$ oyan_waibaloen@yahoo.co.id, ${ }^{2}$ leope.pinnega.gmail.com
}

Naskah dikirim pada tanggal 8 januari 2018, direvisi tanggal 26 Maret 2018, disetujui tanggal 12 April 2018

\section{GOVERNMENT COMMUNICATION AMONG THE REGIONAL GOVERNMENT OFFICIALS IN EAST NUSA TENGGARA PROVINCE}

\begin{abstract}
One problem that is still a challenge in creating synergy among regional government officials regarding the tourism development in East Nusa Tenggara Province is government communication. Therefore the objective of this research is to explore the government communication that occurs among regional government officials in NTT provincial government regarding the tourism development. The theoretical base used is organizational communication theory with the approach of Karl Weick organizational and network theory. This research uses a descriptive qualitative method. The result of this research shows that the government communication among East Nusa Tenggara regional government officials regarding the tourism development experiences various problem. The problem is related to communication type, the communication element, and the relationship dimension in organizational communication. Furthermore, from the perspective of the relationship dimension in government communication, the communication process among regional government officials in NTT provincial government emphasizes the dimensions of superior-subordinate and positional relations.
\end{abstract}

Keywords: government communication, regional government officials, tourism development.

\begin{abstract}
Abstrak. Salah satu problem yang masih menjadi tantangan dalam menciptakan sinergi antar perangkat daerah dalam pengembangan pariwisata di Provinisi Nusa Tenggara Timur (NTT) adalah komunikasi pemerintahan. Penelitian ini bertujuan untuk mengeksplorasi komunikasi pemerintahan yang terjadi antar perangkat daerah lingkup pemerintah Provinsi NTT dalam pengembangan pariwisata. Oleh karena itu, landasan teori yang digunakan adalah komunikasi organisasi dengan pendekatan teori Organisasi Karl Weick dan teori Jaringan. Metode penelitian yang digunakan adalah deskriptif kualitatif. Hasil penelitian menunjukkan bahwa komunikasi pemerintahan antar perangkat daerah lingkup Pemerintah Provinsi NTT dalam pengembangan pariwisata mengalami berbagai problem yang berkaitan dengan tipe-tipe komunikasi, unsurunsur komunikasi, dan dimensi hubungan dalam komunikasi organisasi. Selain itu, dari perspektif dimensi relasi dalam komunikasi pemerintahan, proses komunikasi yang berlangsung lebih menonjolkan dimensi relasi atasan-bawahan dan relasi posisional dalam proses komunikasi tersebut.
\end{abstract}

Kata kunci: komunikasi pemerintahan, perangkat daerah, pengembangan pariwisata. 


\section{PENDAHULUAN}

Pemerintah Provinsi Nusa Tenggara Timur (NTT) menetapkan pengembangan pariwisata sebagai salah satu agenda pembangunan pada tahun 2013-2018. Upaya ini menunjukkan tren pembangunan yang positif. Dari tahun ke tahun, sektor pariwisata di Provinsi NTT terus menunjukkan peningkatan kunjungan wisatawan mancanegara dan domestik. Kunjungan wisatawan mancanegara Tahun 2009-2015 mencapai 441.348 orang. Sedangkan, kunjungan wisatawan domestik tahun 2016 mencapai 397.924 orang (Bappeda Provinsi NTT, 2017).

Menurut Nirwandar (2006) tujuan pengembangan pariwisata pada dasarnya mempunyai spektrum yang lebih besar dari sekedar menjadi lokomotif ekonomi. Pengembangan pariwisata tersebut ditujukan untuk persatuan dan kesatuan bangsa, penghapusan kemiskinan, pembangunan berkesinambungan, pelestarian budaya, pemenuhan kebutuhan hidup dan hak asasi manusia, peningkatan ekonomi dan industri, serta pengembangan teknologi. Pencapaian tujuan-tujuan tersebut memerlukan sinergitas dengan stakeholder terkait, mengingat usaha pengembangan pariwisata adalah usaha multisektor.

Pengembangan pariwisata di Provinsi NTT tidak hanya mengandalkan dinas pariwisata sebagai ujung tombak tetapi juga melibatkan berbagai perangkat daerah dan kalangan birokrat. Menurut Djese (2013), peran pemerintah dari sisi program dan kebijakan dalam pengembangan pariwisata NTT belum berjalan dengan baik. Hal ini dicirikan oleh kurang adanya komunikasi dan koordinasi internal yang baik dan berkesinambungan antar perangkat daerah yang terkait dalam pengembangan sektor pariwisata. Komunikasi dan koordinasi eksternal yang renggang juga terjadi dalam hubungan antara pemerintah dan stakeholder terkait lainnya.

Ini mencerminkan pemerintah daerah sebagai sebuah organisasi yang besar dan kompleks memunculkan konsekuensi dari banyaknya fungsi yang harus diselenggarakan dalam mengatur dan mengurus berbagai urusan wajib dan pilihan yang kewenangannya sesuai peraturan perundangundangan. Dalam pelaksanaannya, kompleksitas urusan-urusan pemerintahan tersebut menuntut adanya pembagian tugas dan spesifikasi yang jelas. Salah satu akibatnya adalah munculnya fenomena ego sektoral di antara perangkat daerah dalam pengembangan pariwisata. Ego sektoral dicirikan dengan minimnya kerjasama antara lembaga pemerintahan dalam pelaksanaan program atau agenda pembangunan. Selain itu, ego sektoral ditunjukkan pula dengan sikap individualisme dalam melaksanakan program pembangunan (Febrian, 2015; Akmal, 2006).

Keberhasilan pengembangan pariwisata ditentukan oleh kebijakan komunikasi pemerintahan yang akan menjawab persoalan ego sektoral. Menurut Beach dalam Silalahi (2004) menekankan bahwa bagaimanapun juga organisasi pemerintahan tidak akan dapat melaksanakan fungsinya, dan tidak akan dapat mengefisienkan dan mengefektifkan penggunaan sumbersumbernya, dan pada akhirnya tidak akan dapat mencapai tujuannya tanpa komunikasi. Dalam penelitiannya Bokau (2013) menegaskan bahwa salah satu aspek yang turut menentukan laju pembangunan yang berlangsung adalah adanya sinergitas antar institusi pemerintah sebagai penggerak dan penentu kebijakan pembangunan. Untuk menggerakkannya, salah satu kunci demi terciptanya kelancaran pembangunan adalah peranan komunikasi pemerintahan di antara para birokrat. Apabila komunikasi pemerintahan tidak berjalan dengan baik maka percepatan pembangunan yang diharapkan terjadi banyak mengalami hambatan atau kendala.

Melalui komunikasi, eksekutif pemerintah atau pejabat pemerintah dapat memengaruhi sikap (attitude), pemahaman (understanding), dan perilaku (behavior) birokrasi dan masyarakat. Adanya kemungkinan organisasi pemerintah mencapai tujuannya sesuai dengan harapan, jika para pejabat pemerintah atau birokrat memahami berbagai peristiwa komunikasi 
yang terjadi dalam organisasi pemerintah, seperti penerimaan pesan, pemahaman terhadap pesan, dan bagaimana pesan dilaksanakan dengan benar. Arus penyampaian dan penerimaan pesan dilakukan melalui jaringan yang sifat hubungannya saling tergantung satu sama lain berdasarkan aturan-aturan formal. Pesan yang disampaikan dan yang diterima bukan saja berupa informasi, melainkan juga penyebaran ide-ide (sharing ideas), instruksi (instruction), atau perasaan-perasaan (feelings) berhubungan dengan tindakan dan kebijakan pemerintah (Malone dalam Silalahi, 2004; Harris, 2002). Dengan demikian, tiap orang yang terlibat dalam penyelenggaraan pemerintahan demokratis merupakan bagian dari proses komunikasi pemerintahan, baik sebagai sender di satu waktu, dan di waktu lain ia menjadi receiver (Silalahi, 2004).

Dalam penelitian ini, pembahasan tentang komunikasi antara stakeholder dalam pengembangan pariwisata di Provinsi NTT dibatasi pada perangkat daerah lingkup Pemerintah Provinsi NTT, dan tidak termasuk stakeholder lainnya seperti masyarakat, dunia usaha, LSM, dan sebagainya. Pembatasan ini dilakukan dengan argumentasi bahwa pemerintah daerah masih memiliki peran yang dominan dalam proses pembangunan (Siagian, 2010). Oleh karena itu, penelitian ini mengacu pada pertanyaan penelitian, yakni bagaimana keberlangsungan komunikasi pemerintahan antar perangkat daerah lingkup Pemerintah Provinsi NTT dalam pengembangan pariwisata? Tujuan penelitian ini adalah untuk mendeskripsikan atau mengeksplorasi keberlangsungan komunikasi pemerintahan antar perangkat daerah lingkup Pemerintah Provinsi NTT dalam pengembangan pariwisata.

\section{LANDASAN KONSEP}

\section{Komunikasi Pemerintahan}

Komunikasi pemerintahan adalah proses berbagi informasi, ide, gagasan atau perasaan, dan sikap di antara aparatur pemerintah untuk internal organisasi dan eksternal organisasi, atau sebaliknya.
Komunikasi dalam kehidupan organisasi (pemerintahan) memiliki dua tipe yaitu, komunikasi internal dan komunikasi eksternal. Komunikasi internal terdiri dari downward communication atau komunikasi ke bawah dan upward communication atau komunikasi ke atas (Hasan, 2007).

Komunikasi ke bawah merupakan aliran pesan yang bergerak dari pimpinan ke bawahan mengikuti hierarki organisasi. Pesan yang disampaikan umumnya berupa instruksi jabatan atau tugas, cara mengerjakan tugas, penjelasan prosedur dan kebijakan, misi dan tujuan, dan umpan balik kepada pegawai, pemberian motivasi untuk bekerja lebih baik, menginformasikan tujuan organisasi sebagai sesuatu yang harus dicapai (Harris, 2002; Katz \& Kahn; Huseman dalam Silalahi, 2004; Pace \& Faules, 2010).

Sebaliknya, komunikasi ke atas merupakan aliran pesan yang mengikuti jaringan dari bawahan ke pimpinan. Pesan yang disampaikan biasanya berupa laporan pelaksanaan pekerjaan, keluhan pegawai, sikap, dan perasaan pegawai tentang berbagai hal, pengembangan prosedur dan teknik, informasi tentang produksi dan hasil yang dicapai. Fungsinya meliputi penyampaian informasi tentang pekerjaan ataupun tugas yang sudah dilaksanakan, penyampaian informasi tentang persoalan-persoalan pekerjaan ataupun tugas yang tidak dapat diselesaikan, penyampaian saran-saran perbaikan, penyampaian keluhan bawahan tentang dirinya sendiri dan pekerjaannya (Harris, 2002; Katz \& Kahn; Huseman dalam Silalahi, 2004; Pace \& Faules, 2010).

Pace \& Faules (2010) menjelaskan bahwa komunikasi dalam sebuah organisasi berlangsung dalam berbagai bentuk relasi atau hubungan, seperti: hubungan antar persona, hubungan posisional, hubungan atasan-bawahan, dan hubungan berurutan. Dalam komunikasi pemerintahan, seringkali terjadi hubungan-hubungan yang dominan, seperti hubungan atasan-bawahan, hubungan posisional, dan hubungan berurutan. Hubungan atasan-bawahan menggambarkan bagaimana jabatan-jabatan disusun dalam urutan hierarki, sehingga proses komunikasi yang berlangsung mengikuti ciri hubungan tersebut. Hubungan posisional ditentukan 
oleh struktur otoritas dan tugas-tugas fungsional anggota organisasi. Sedangkan, hubungan berurutan (serial relationship) menunjukkan bagaimana informasi disampaikan ke seluruh organisasi formal melalui suatu proses. Dalam proses ini, orang di puncak hierarki mengirimkan pesan kepada orang kedua yang kemudian mengirimkan pesan lagi kepada orang ketiga.

Selanjutnya, Jablin dalam Pace \& Faules (2010) menjelaskan bahwa komunikasi atasan-bawahan memunculkan sembilan kategori masalah, di antaranya: pola interaksi, keterbukaan, distorsi ke atas, pengaruh ke atas (efek pelz), jarak informasisemantik, atasan efektif versus atasan tidak efektif, sifat-sifat pribadi atasan dan bawahan, umpan balik dan pengaruh variabel-variabel organisasi sistemik pada kualitas komunikasi. Penelitian dalam komunikasi atasan-bawahan menunjukkan bahwa bawahan cenderung mengatakan kepada atasan apa yang ingin didengar oleh atasan menurut perkiraannya, dan memberi informasi kepada atasan yang menggambarkan kelebihan bawahan, atau paling sedikit, tidak mencerminkan kekurangan bawahan tersebut (Krivonos; Maier, Hoffman \& Read; Mellinger; Pelz; Read dalam Pace \& Faules, 2010).

Komunikasi pemerintahan yang berdimensi internal dimaksudkan untuk mengirim atau menerima informasi dan tugas (task information) antara pejabat administrator, pengawasan, dan aparatur. Untuk mengirim dan/atau menerima informasi yang berhubungan dengan tugas, proses komunikasi membutuhkan jaringan komunikasi atau jaringan informasi. Dalam organisasi pemerintahan, jaringan komunikasi lebih cenderung kaku (rigid).

\section{Komunikasi Organisasi}

$\begin{array}{rrr}\text { Salah } & \text { satu teori yang menjadikan } \\ \text { komunikasi } & \text { sebagai } & \text { dasar bagi }\end{array}$ pengorganisasian manusia dan memberikan sebuah dasar pemikiran untuk memahami bagaimana manusia berorganisasi adalah teori dari Karl Weick. Menurut teori ini, organisasi bukanlah susunan yang terbentuk oleh posisi dan peran, tetapi oleh aktivitas komunikasi. Organisasi itu sendiri merupakan sesuatu yang dicapai manusia melalui sebuah proses komunikasi yang berkelanjutan. Organisasi terbentuk karena adanya interaksi antara manusia. Oleh karena itu, semua perilaku manusia dihubungkan karena adanya ketergantungan antara perilaku yang satu dengan yang lainnya (Littlejohn \& Foss, 2009).

Menurut Weick, kegiatan berorganisasi berfungsi untuk mengurangi ketidakpastian informasi. Istilah kunci teoretis Weick adalah equivocality, yang berarti ketidakpastian, kesulitan, ambiguitas, dan kurangnya keterdugaan. Semua informasi dari lingkungan sekitar bersifat samar-samar atau ambigu pada beberapa tingkatan. Kegiatan berorganisasi dirancang untuk mengurangi kurangnya ketidakpastian ini. Tidak semua interaksi sama pentingnya dalam mengurangi ketidakpastian, tetapi setiap usaha berkontribusi. Tingkat equivocality yang dialami akan berbeda dalam setiap situasi, tetapi seringkali cukup besar, dan untuk menguranginya akan memerlukan implikasi organisasi yang besar (Littlejohn \& Foss, 2009).

Teori lainnya tentang komunikasi dalam berorganisasi adalah teori jaringan. Teori jaringan menekankan bahwa jaringan merupakan susunan sosial yang diciptakan oleh komunikasi antar individu dan kelompok yang menciptakan mata rantai. Mata rantai tersebut merupakan jalur komunikasi dalam sebuah organisasi yang ditentukan oleh aturan-aturan organisasi dan mendasari jaringan formal. Sebaliknya, jaringan yang berkembang adalah saluran-saluran informal yang dibangun bukan oleh regulasi formal organisasi tetapi oleh kontrak regular seharihari antara anggotanya (Littlejohn \& Foss, 2009).

\section{Telaah Riset Terdahulu}

Penelusuran terhadap penelitianpenelitian terdahulu menemukan beberapa penelitian yang berkaitan dengan komunikasi pemerintahan dalam pengembangan pariwisata. Penelitian tentang pengembangan pariwisata di NTT telah dilakukan oleh Badan Penelitian dan Pengembangan Daerah Provinsi NTT dengan fokus penelitian meliputi potensi dan strategi pengembangan pariwisata (Salim, 2011), strategi 
pengembangan pariwisata (Djese, 2013), dan model pengembangan pariwisata berbasis masyarakat (Nugraha, 2015). Setyowati (2016) dalam risetnya yang berjudul Strategi Komunikasi yang Mendukung Perkembangan Pariwisata Berbasis Ekonomi Kerakyatan mengungkapkan bahwa salah satu strategi komunikasi yang digunakan untuk mendukung perkembangan pariwisata adalah mengembangkan komunikasi jaringan dan merumuskan PRA (Participatory Rural Appraisal) sebagai salah satu metode untuk membantu masyarakat. PRA yang dikembangkan oleh Robert Chambers berdasarkan atas prinsip dan teknik yang harus dikuasai oleh para fasilitator atau pemandu dalam melakukan model partisipatif. Tujuannya adalah untuk penjaringan informasi dan menjalankan proses komunikasi selanjutnya. Meskipun penelitian ini tidak menelaah secara khusus komunikasi pemerintahan namun dalam tulisannya ditekankan pentingnya membangun sebuah model atau metode komunikasi yang efektif dan efisien oleh suatu institusi dalam pengembangan pariwisata.

Ruijer (2013) dalam risetnya yang berjudul Proactive Transparency and Government Communication in the USA and the Netherlands mengembangkan teori Komunikasi Pemerintah dan sebuah model dari berbagai literatur terkait dengan transparansi sebagai hubungan kelembagaan. Ruijer (2013) yang memfokuskan pada hubungan akuntabilitas dan legitimasi, berpendapat bahwa konsep akuntabilitas relasional menunjukkan apresiasi terhadap struktur komunikatif yang akuntabel dan transparan dalam komunikasi pemerintahan.

\section{METODE PENELITIAN}

Metode penelitian yang digunakan adalah kualitatif dengan pendekatan studi kasus. Pendekatan studi kasus dalam penelitian ini akan mendalami gencarnya pengembangan pariwisata yang dilaksanakan selama tahun 2016-2017 oleh Provinsi NTT, sehingga terjadi peningkatan kunjungan wisatawan yang signifikan. Pengembangan pariwisata saat ini masih terpusat pada satu titik saja dan kurang melibatkan sektor-sektor yang lainnya dalam pemerintahan. Melalui pendekatan studi kasus, penelitian akan mengeksplorasi proses komunikasi pemerintahan yang berlangsung antar perangkat daerah dalam pengembangan pariwisata di Provinsi NTT.

Satuan kajian dalam penelitian ini menekankan pada proses pertukaran pesan atau informasi tentang agenda pengembangan pariwisata di Provinsi NTT antar perangkat daerah lingkup Pemerintah Provinsi NTT. Berdasarkan teknik purposive sampling, informan penelitian meliputi pejabat adiministrator dan pengawas pada 15 perangkat daerah di lingkup Pemerintah Provinsi NTT, di antaranya Dinas Pariwisata, Dinas Pertanian dan Perkebunan, Dinas Kehutanan, Dinas Perindustrian, Dinas Tenaga Kerja dan Transmigrasi, Dinas Peternakan, Dinas Penanaman Modal dan Pelayanan Perizinan Satu Pintu, Dinas Koperasi dan UMKM, Dinas Energi dan Pertambangan, Dinas Pekerjaan Umum, Dinas Kebudayaan, Dinas Perhubungan, Dinas Kesehatan, Bappeda dan Biro Perekonomian. Kelima belas perangkat daerah ini ditetapkan dalam RPJMD Provinsi NTT 2013-2018 dalam rangka mengembangkan agenda pariwisata.

Untuk mendapatkan data primer, peneliti melakukan wawancara mendalam (depth interview) dengan para informan yang sudah ditentukan. Peneliti juga melakukan observasi partisipan terhadap pelaksanaan rapat koordinasi pengembangan pariwisata oleh Biro Perekonomian Setda Provinsi NTT. Sedangkan, untuk memperkuat data primer, peneliti melakukan studi dokumen berupa Renstra dan Renja kelima belas perangkat daerah tersebut. Apabila dalam pengumpulan data, terdapat data yang keabsahannya diragukan, maka dilakukan teknik pemeriksaan keabsahan data yang meliputi; perpanjangan keikutsertaan, ketekunan pengamatan, triangulasi dengan sumber data dan teori, penambahan referensi (Bungin, 2007; Moeleong, 2009).

Hasil penelitian dianalisis dengan menggunakan domain analysis. Artinya, analisis hasil penelitian ini hanya ditargetkan 
untuk memperoleh gambaran seutuhnya dari objek yang diteliti, tanpa harus dirinci kembali secara detail unsur-unsur yang ada dalam keutuhan objek penelitian tersebut. Analisis data dilakukan secara eklektik, dengan pemahaman bahwa penggunaan satu atau lebih teori akan ditentukan berdasarkan objek penelitian dan dilakukan secara terusmenerus selama proses penelitian (Bungin, 2007).

\section{HASIL PENELITIAN DAN PEMBAHASAN}

\section{Dimensi Komunikasi Pemerintahan antar Perangkat Daerah di Lingkup Pemerintah Provinsi NTT}

Dalam pengembangan pariwisata berlangsung dalam dua dimensi komunikasi dan berbagai tipologi komunikasi organisasi pada umumnya, antara lain; komunikasi internal, eksternal, vertikal, dan horizontal. Setiap tipe komunikasi yang digunakan tersebut tetap terpola dalam suatu sistem komunikasi pemerintahan yang lebih besar, yakni birokrasi. Sedangkan, komunikasi eksternal berkaitan dengan komunikasi antar perangkat daerah dengan pihak luar (Pemda, swasta, dan sebagainya). Hasil penelitian menunjukkan bahwa komunikasi pemerintahan internal yang terjadi baik vertikal maupun horizontal tidak hanya dalam bentuk komunikasi tertulis tetapi juga dalam bentuk komunikasi lisan. Komunikasi lisan yang dilakukan dimaksudkan untuk mendorong kerjasama antar perangkat daerah berkenaan dengan pembagian tugas atau tupoksi dalam pengembangan pariwisata, sedangkan komunikasi tertulis sebatas mendukung keberlangsungan komunikasi lisan, seperti surat-menyurat.

Temuan penelitian menunjukkan pula adanya pengecualian dalam penggunaan tipe komunikasi, seperti: komunikasi vertikal dan horizontal dalam pembahasan program kegiatan antar perangkat daerah mengenai agenda pariwisata. Hal ini disebabkan karena muatan isi pesan dan siapa sumber pesannya yang pada konteks tertentu dapat mengubah pola komunikasi. Pilihan penggunaan media komunikasi juga seringkali berbeda dan berubah-ubah dalam pelaksanaannya. Berikut petikan hasil wawancaranya: "Koordinasi dan komunikasi antar perangkat daerah kurang jalan, seperti hasil pembicaraan tidak dikancing dalam suatu program atau kegiatan. Karena, masing-masing perangkat daerah punya program atau kegiatan sendiri yang berkaitan dengan pariwisata, seperti di Dinas Pertanian ada agrowisata. Program ini tidak dikomunikasikan dengan Dinas Pariwisata" (Wawancara dengan Benny Wahon, Dinas Pariwisata Provinsi NTT).

Dari beberapa pilihan tipe komunikasi pemerintahan yang digunakan, beberapa tipe komunikasi diidentifikasikan ke dalam bentuk atau jenis komunikasi yang digunakan di antara para birokrat, seperti rapat, Musrembang, dan forum diskusi. Pilihan penggunaan bentuk komunikasi vertikal atau horizontal lebih cenderung pada pelaksanaan rapat. Tujuannya adalah mendiseminasi informasi dan menyamakan persepsi tentang suatu agenda kegiatan. Salah satu contoh rapat adalah rapat koordinasi (rakor) tentang pengembangan pariwisata dan focus group discussion ( $F G D)$. Rapat koordinasi yang dilaksanakan sebatas berbagi informasi terkait bagaimana pengembangan pariwisata di Provinsi NTT. Respon terhadap urgensi pelaksanaan rapat tidak seperti yang diharapkan karena peserta rapat yang hadir rata-rata tingkat eselon IV ke bawah. Sehingga, output dari pelaksanaan rapat tidak memberikan dampak yang signifikan terhadap pengembangan pariwisata di 22 Kabupaten/Kota di Provinsi NTT. Agenda komunikasi pada jenis atau bentuk komunikasi ini memberi penekanan pada beberapa poin, di antaranya: butuh sinergitas antar perangkat daerah, kabupaten/kota seProvinsi NTT dan keterlibatan pihak swasta dalam pengembangan pariwisata di Provinsi NTT.

Hasil observasi partisipan mengungkapkan pula bahwa rapat koordinasi yang terjadi memperlihatkan adanya masalah dalam komunikasi pemerintahan. Pelaksanaan rapat koordinasi yang diselanggarakan oleh Biro Perekonomian Setda Provinsi NTT ini tidak mencapai suatu konsensus bersama tentang rencana aksi nyata dalam pengembangan pariwisata di Provinsi NTT. 
Agenda pariwisata sebatas dilihat dari persoalan infrastruktur yang masih menjadi kendala di beberapa destinasi wisata di Provinsi NTT. Masing-masing utusan dari 22 kabupaten/kota di Provinsi NTT meminta perhatian dari Pemerintah Provinsi NTT untuk mengatasi masalah ini.

Temuan penelitian lainnya mengungkapkan bahwa komunikasi berbentuk rapat berjalan sudah efektif. Akan tetapi, kontinuitas dari mutual understanding yang disepakati dalam rapat kurang mendapat respon dalam aksi nyata. Pelaksanaan rapat lebih didominasi dengan penjaringan aspirasi dari kabupaten/kota yang lebih menyoroti persoalan infrastruktur. Distribusi atau diseminasi pesan secara terorganisir terkait pengembangan pariwisata menemui kendala dalam encoding di penerima pesan di level selanjutnya dalam birokrasi.

"Kita bicara sebatas dukungandukungan tetapi pelaksanaannya sampai sekarang, biasa-biasa saja, tidak sinkron. Kita sekedar hanya omong-omong tapi sebentar berubah lagi, lupa lagi" (Wawancara dengan Gabriel Beni, Dinas Pertanian Provinsi NTT).

Secara spesifik, masalah komunikasi pemerintahan yang ditemukan di sini adalah pertukaran pesan atau penyampaian pesan kurang fokus pada agenda utama komunikasi. Masing-masing peserta rapat memberi penekanan pada isi pesan yang disampaikan supaya segera mendapat perhatian. Komunikasi pemerintahan yang berlangsung tidak berada pada konteks agenda utama tetapi memunculkan agenda-agenda lainnya yang mengarah pada ego sektoral dan ego wilayah. Rapat koordinasi diwarnai dengan distorsi pesan sebagai akibat dari penyampaian pesan yang tumpang-tindih, benturan pesan, akumulasi pesan, dan sikap tidak mendengarkan.

Selain itu, temuan di lapangan menunjukkan bahwa pilihan tipe komunikasi pemerintahan yang dilaksanakan oleh kalangan birokrat antar perangkat daerah seringkali tidak sesuai dengan agenda komunikasi. Hal ini berimplikasi pada rendahnya responsivitas keterlibatan perangkat daerah dalam kegiatan komunikasi terkait agenda komunikasi pengembangan pariwisata di Provinsi NTT. Berikut petikan hasil wawancaranya: "Komunikasi di antara kita birokrat janganlah terlalu kaku, maksudnya hanya tunggu pelaksanaan rapat atau sejenisnya dulu baru kita bicara tentang pariwisata. Komunikasi yang efektif kan kita bisa gunakan jenis komunikasi atau media komunikasi lainnya dalam bertukar informasi supaya action di lapangan cepat dan tepat waktu. "Pengalaman saya, kalo secara legal surat-menyurat atau urusan adminstrasi harus dilaksanakan, akan tetapi hal ini sudah kita rasakan bersama, memakan waktu yang lama. Sedangkan, kadang-kadang kita dikejar oleh waktu untuk segera mengeksekusi suatu kegiatan. Oleh karena itu, biasanya kita harus ikuti dengan lisan" (Wawancara dengan Untung, Dinas Nakertrans Provinsi NTT).

\section{Komunikasi Pemerintahan antar Perangkat Daerah dalam Pengembangan Pariwisata Berlangsung dalam Tingkatan yang Berbeda-Beda pada Unsur Pesan}

Pesan yang disampaikan atau dipertukarkan berbeda dalam frekuensi, intensitas, kredibilitas, dan kebaruan. Hasil penelitian di lapangan menunjukkan bahwa pesan yang disampaikan berkaitan dengan agenda pengembangan pariwisata menunjukkan frekuensi yang berbeda-beda antar Dinas Pariwisata dengan perangkat daerah yang terkait. Isi pesan yang disampaikan tentang pengembangan pariwisata beragam, sehingga memengaruhi intensitas pesan yang disebarkan ke setiap perangkat daerah. Masing-masing perangkat daerah memaknai pesan tentang pengembangan agenda pariwisata dari perspektif perencanaan yang berbeda-beda karena disesuaikan dengan visi dan misi perangkat daerahnya.

Selain itu, komunikasi pemerintahan antar perangkat daerah dalam pengembangan pariwisata ditentukan oleh beberapa indikator yang spesifik, seperti terlihat pada source of messeage, dan content agenda komunikasi lainnya, antara lain jenis program atau kegiatan. Berkaitan dengan source of messeage, temuan penelitian mengungkapkan bahwa aliran informasi tentang agenda pengembangan pariwisata bersumber dari beberapa sumber pesan (perangkat daerah) yang memiliki juga kewenangan dalam 
pelaksanaan agenda ini. Meskipun sasaran akhir pertukaran informasi yang dilaksanakan mengarah pada agenda utama pengembangan pariwisata, namun masing-masing sumber komunikasi memiliki packaging informasi yang berbeda-beda. Fakta inilah yang potensial memunculkan ego sektoral dalam urusan pelaksanaan pengembangan pariwisata di lapangan. Misalnya, dalam pengembangan pariwisata, Dinas Pertanian Provinsi NTT memiliki program agrowisata. Dinas Perindustrian memiliki program kampung tenun. Program-program ini tidak dikomunikasikan dengan Dinas Pariwisata sebagai leading sector.

Berkaitan dengan hal tersebut, temuan di lapangan menunjukkan bahwa agenda komunikasi seringkali belum mencapai mutual understanding tetapi tetap dilaksanakan. Hal ini disebabkan karena orientasi pelaksanaan komunikasi belum memerhatikan aspek prosedural, sehingga terkadang terjadi keterlambatan dalam pelaksanannya. Pelaksanaan komunikasi juga sekedar memenuhi target realisasi tanpa memperhatikan kualitas pelaksanaan kegiatan. Selain itu, komunikasi sebagai ruang untuk menyampaikan setiap agenda lainnya yang dinilai penting oleh setiap perangkat daerah dalam rangka mendukung agenda utama, yakni pengembangan pariwisata seringkali diabaikan dalam pelaksanaannya. Hal ini disebabkan karena dalam tahap perencanaan seringkali terjadi miskomunikasi yang menyebabkan perbedaan orientasi dan konsentrasi pekerjaan. Pertukaran informasi kurang memperlihatkan adanya transparansi pesan tentang anggaran dan program atau kegiatan yang dilaksanakan dan ditunjukkan pula dengan kebijakan yang berubah-ubah. Berikut petikan hasil wawancaranya: "Komunikasi dan koordinasi dengan perangkat daerah lainnya dalam hal pengembangan pariwisata jarang dilakukan. Kita palingan rapat dengan Sekda terkait enam tekad, temasuk agenda pariwisata. Terkait agenda pariwisata, komunikasi antar perangkat daerah bisa jalan kalau ada undangan dari Sekda atau Gubernur. Tetapi, kalau tidak masing-masing perangkat daerah urus sendiri karena sudah ada di renstranya. Di sini komunikasi tidak jalan" (Wawancara dengan Gabriel Beni, Dinas Pertanian Provinsi NTT).

Temuan penelitian mengungkapkan pula, bahwa beberapa karakter pesan memengaruhi interdependensi komunikator dengan komunikan dalam pertukaran informasi tentang agenda pariwisata. Misalnya, intensitas pesan dan frekuensi pesan tentang agenda unggulan dalam pengembangan pariwisata. Pesan yang berkaitan dengan hal ini, biasanya telah mendapat dukungan langsung dari kepala daerah. Akan tetapi, dalam pelaksanaannya masih saja ditemukan minimnya komunikasi antar perangkat daerah, sehingga seringkali kurang mendapat support atau dukungan. Berikut petikan hasil wawancaranya: "Kami di dinas ini sebenarnya sangat menyesalkan kegiatan Dinas Pariwisata yang selama ini terjadi, ini dikarenakan Dinas Pariwisata tidak memberikan informasi. Kalau mereka koordinasi dan komunikasi dengan kami, kami dapat terlibat juga dalam kegiatan tersebut. Contoh yang paling nyata dan belum lama terjadi adalah Tour de Flores, mereka terkesan jalan sendiri saja dan tidak berkoordinasi dan berkomunikasi dengan perangkat daerah terkait untuk saling bahumembahu untuk melaksanakan kegiatan tersebut" (Wawancara dengan Dasal Mateus, Dinas Pertanian Provinsi NTT).

Komunikasi pemerintahan antar perangkat daerah dalam pengembangan pariwisata di Provinsi NTT belum menunjukkan aspek pembaruan dan kebaruan dalam strategi komunikasi organisasi. Komunikasi pemerintahan antar perangkat daerah dalam pengembangan pariwisata masih saja berkutat dengan pola komunikasi yang lazim dalam organisasi pemerintahan. Berikut ini petikan hasil wawancaranya: "Bukan rahasia lagi, kebiasaan yang terjadi selama ini adalah kelambanan dalam berkomunikasi di antara perangkat daerah. Komunikasi yang terjalin lamban karena menyangkut administrasi" (Wawancara dengan Benny Wahon, Dinas Pariwisata Provinsi NTT).

Sedangkan, yang berkaitan dengan content agenda komunikasi lainnya, temuan penelitian mengungkapkan bahwa penentuan agenda-agenda tersebut bertujuan untuk 
mendukung kebijakan pengembangan pariwisata sebagai agenda utama. Ini memengaruhi juga kualitas agenda komunikasi yang dilaksanakan. Hasil observasi penelitian mengungkapkan bahwa agenda-agenda lain yang dibicarakan dalam agenda komunikasi pengembangan pariwisata meliputi pembenahan infrastruktur dan perbaikan infrastruktur pendukung lainnya. Sedangkan, dalam studi dokumen, diketahui bahwa dalam penyusunan Renstra dan Renja beberapa perangkat, masing-masing perangkat daerah menyusun atau menetapkan program-program atau kegiatan yang tidak berhubungan langsung dengan pengembangan pariwisata. Program-program atau kegiatan yang disusun berdasarkan visi dan misi masing-masing perangkat daerah, tidak bersinergis dengan Dinas Pariwisata Provinsi NTT.

\begin{tabular}{|c|c|}
\hline unikasi & pemerintahan \\
\hline $\begin{array}{l}\text { kat daerah } \\
\text { gkatkan }\end{array}$ & $\begin{array}{l}\text { bertujuan } \\
\text { sinergitas }\end{array}$ \\
\hline
\end{tabular}
pengembangan pariwisata di Provinsi NTT. Sedangkan urusan kebijakan ditentukan oleh posisi pelaku komunikasi yang memiliki otoritas secara kelembagaan. Secara organisatoris komunikasi pemerintahan, Bappeda Provinsi NTT memiliki otoritas dalam menciptakan iklim komunikasi pemerintahan yang bersinergis antar perangkat daerah. Akan tetapi dalam pelaksanaannya komunikasi pemerintahan yang terjadi antar perangkat daerah kurang intensif saat perencanaan atau penyusunan program kerja. Berikut petikan hasil wawancaranya: "Iya semua kegiatan yang akan dilaksanakan memang harus direncanakan, karena itu berkaitan dengan penganggaran dan tujuan pembangunan. Akan tetapi, ada pula kegiatan-kegiatan yang merupakan kegiatan yang bersifat aktual dan harus segera dilaksanakan, ini yang kadangkadang kita kelabakan. Jika dilihat dari aspek perencanaan yaa memang tidak sesuai akan tetapi itu hal tersebut harus dilaksanakan, ini sebenarnya OPD terkait yang harus sesegera mungkin membangun komunikasi atau koordinasi dengan berbagai pihak, terlebih di Bappeda sehingga jangan terkesan kami pun kaget ketika kegiatan tersebut berjalan." "Nah itu akibat koordinasi, komunikasi seperti yang dibilang tadi. Koordinasi dan komunikasi kita tidak jalan. Kita hanya sebatas omong pada saat rapat, ya harus gini, ya gini, tapi bukti yang dilaksanakan amburadul saja. Seperti perhubungan harus bangun jalan di daerahdaerah destinasi wisata, tetapi renstra kita sudah katakan begini, yah begini sudah yang kita buat. Harusnya pada saat asistensi renstra dengan Bappeda, orang Bappeda harus liat..." (Wawancara dengan Gabriel Beni, Dinas Pertanian Provinsi NTT).

Iklim komunikasi pemerintahan antar perangkat daerah dalam pengembangan pariwisata mencirikan iklim komunikasi organisasi di lingkungan birokrasi. Secara umum, sistem komunikasi birokrasi pemerintahan menonjolkan alur informasi secara berjenjang. Ciri sistem birokrasi yang hierarkis teraktualisasi juga dalam sistem komunikasi pemerintahan antar perangkat daerah lingkup Pemerintah Provinsi NTT dalam pengembangan agenda pariwisata. Hasil penelitian mengungkapkan bahwa karakteristik yang menonjol dalam sistem komunikasi pemerintahan antar perangkat darah dalam pengembangan pariwisata meliputi: prosedur komunikasi secara berjenjang, adanya sikap saling menunggu, responsivitas yang lamban (efek komunikasi), prioritas pesan yang berbeda-beda antar perangkat daerah dalam hal pengembangan pariwisata, minimnya informasi dan media komunikasi masih mengandalkan suratmenyurat (komunikasi tertulis).

Hal menarik lainnya yang diamati adalah komunikasi yang terjadi diletakkan pada kerangka filofosi komunikasi yang berbeda dengan sistem komunikasi birokrasi. Komunikasi pemerintahan yang terjadi sekedar sebagai instrumen untuk mengaktualisasikan rencana aksi atau program, bukan sebagai ruang untuk menyampaikan dan menginternalisasikan setiap gagasan yang konstruktif. Komunikasi yang dijalin tidak diarahkan pada penyamaan persepsi atau mutual understanding tentang suatu kegiatan atau program yang berkaitan dengan agenda pariwisata tetapi sebatas informasi sepihak. Komunikasi yang terjadi juga kurang fleksibel di antara para pejabat administrator dan pengawas antar perangkat daerah terkait. 
Dari beberapa temuan penelitian tersebut di atas, hasil analisis dapat dielaborasi dari perspektif komunikasi pemerintahan.

\section{Analisis Problematika Komunikasi Pemerintahan antar Perangkat Daerah dalam Pengembangan Pariwisata di Provinsi NTT menurut Tipe Komunikasi Organisasi}

Secara umum, pelaksanaan komunikasi pemerintahan antar perangkat daerah terkait pengembangan pariwisata di Provinsi NTT dikelompokkan ke dalam beberapa tipe, di antaranya komunikasi vertikal dan horizontal. Pilihan tipe komunikasi disesuaikan dengan agenda komunikasi pengembangan pariwisata yang memuat pesan-pesan tentang spesifik program atau kegiatan. Dalam pelaksanaannya, komunikasi pemerintahan berdimensi internal yang terjadi antar perangkat daerah lingkup Pemerintah Provinsi NTT dihadapkan pada hambatan internal, yakni sistem komunikasi birokrasi. Bagaimanapun juga sistem komunikasi birokrasi berpengaruh besar terhadap kegiatan komunikasi pemerintahan yang secara khas dianggap sebagai organisasi yang mengadopsi ciri-ciri birokrasi (Silalahi, 2004).

Dari berbagai tipe komunikasi pemerintahan yang digunakan diketahui bahwa komunikasi pemerintahan internal antar perangkat daerah lingkup Pemerintah Provinsi NTT lebih merupakan komunikasi dalam hubungan kerja. Masing-masing bentuk komunikasi memiliki perbedaan fungsi. Hubungan kerja dalam komunikasi pemerintahan dikenal pula dengan adanya komunikasi informasi dan komunikasi penugasan. Untuk mendiseminasi informasi dalam proses komunikasi pada umumnya digunakan komunikasi informasi. Informasi yang disampaikan biasanya oleh pejabat eselon yang lebih tinggi ke pejabat eselon yang lebih rendah. Melalui penyampaian informasi, aparatur birokrasi yang berada di bawah kewenangannya menerima dan memahami informasi dan ide itu dengan pengertian yang sama (Gondokusumo dalam Silalahi, 2004).
Dalam komunikasi pemerintahan antar perangkat daerah di lingkungan birokrasi, keberhasilan dari tujuan komunikasi tidak sekedar ditentukan dengan adanya penyampaian informasi atau tugas. Meskipun pejabat eselon lebih tinggi berkeinginan agar tugas itu dikerjakan sampai selesai menurut norma dan standar yang berlaku, namun proses komunikasi tidak berhasil apabila informasi yang dikomunikasikan oleh pihak pertama tidak dapat ditangkap dan dipahami oleh pihak kedua atau maksud yang diperoleh pihak kedua tidak sesuai dengan maksud yang disampaikan. Dalam hubungan kerja informasi dikomunikasikan untuk digunakan dalam bidang kerja pihak kedua. Komunikasi dikatakan berhasil apabila hasil kerja pihak kedua itu mencerminkan penerapan informasi yang diperolehnya. Oleh karena itu diperlukan kesepahaman dalam hal isi informasi dan pelaksanaannya (Gondokusumo dalam Silalahi, 2004).

Hasil penelitian menunjukkan bahwa hubungan kerja terkait pengembangan agenda pariwisata dalam komunikasi pemerintahan antar perangkat daerah minim terjadi. Sebagai akibatnya, dalam bentuk komunikasi informasi, aliran informasi terkait agenda pengembangan pariwisata antar perangkat daerah juga kurang berjalan.

Hal ini berimplikasi terhadap komunikasi penugasan yang jarang dilakukan di antara para Aparatur Sipil Negara perangkat daerah lingkup Pemerintah Provinsi NTT dalam pengembangan pariwisata. Tentunya, komunikasi pemerintahan seperti ini yang memutus jaringan komunikasi dalam pengembangan pariwisata sekalipun pada kesempatan tertentu telah dilakukan komunikasi informasi dari pimpinan, misalnya sekretaris daerah ke masing-masing pejabat administrator setiap perangkat daerah yang terlibat dalam pengembangan pariwisata.

Rendahnya komunikasi informasi dan komunikasi penugasan antar perangkat daerah dalam pengembangan pariwisata menyebabkan terjadinya iklim komunikasi pemerintahan yang kurang kondusif. Hal ini dicirikan dengan rendahnya fleksibilitas komunikasi yang terjadi di antara para birokrat (pimpinan perangkat daerah, pejabat 
administrator, dan pengawas) antar perangkat daerah terkait. Secara umum, komunikasi pemerintahan antar perangkat daerah lingkup Pemerintah Provinsi NTT dalam pengembangan pariwisata menghadapi berbagai masalah yang berkaitan dengan peran birokrasi, tujuan atau sasaran organisasi yang tidak kompatibel dengan harapan, transparansi, jadwal dan perencanaan program, dan beberapa keputusan yang tidak relevan (Widhiastuti, 2013). Di samping itu, sistem komunikasi birokrasi memiliki juga hambatan yang berhubungan langsung dengan gaya kepemimpinan, gaya komunikasi dan kompetensi komunikasi yang kurang baik (Lubis, 2012). Susanto (2017) menandaskan bahwa reformasi birokrasi masih menghadapi berbagai hambatan yang bersifat internal dalam tubuh birokrasi pemerintahan yang masih melembagakan pola komunikasi paternalistik. Buluamang (2017) menegaskan bahwa sistem komunikasi birokrasi dihadapkan pada hambatan transparansi pesan yang menjadi bagian dari transparansi komunikasi dalam proses komunikasi pemerintahan secara keseluruhan antara para birokrat. Persoalan transparansi pesan ditemukan pada transparansi anggaran dan transparansi kebijakan komunikasi, khususnya komunikasi atas ke bawah. Sistem komunikasi yang demikian berdampak pada proses pertukaran informasi atau pesan yang terjadi tidak mengarah pada sinergitas program atau kegiatan tentang pengembangan pariwisata di Provinsi NTT.

Komunikasi pemerintahan yang terjadi antar perangkat daerah di lingkup Pemerintah Provinsi NTT dalam pengembangan pariwisata cenderung didominasi oleh komunikasi vertikal (vertical communication) dengan aliran informasi dari atas ke bawah (downward communication) berdasarkan hubungan kekuasaan (power relationship) dalam hierarki. Dalam bentuk komunikasi seperti ini, seringkali proses komunikasi yang berlangsung dihadapkan pada beberapa persoalan komunikasi atasan-bawahan. Hasil penelitian menunjukkan bahwa beberapa masalah yang muncul secara khusus dalam tipe komunikasi ini antara lain: kurangnya keterbukaan antara para pejabat di antara beberapa perangkat daerah terkait yang mengembangkan agenda pariwisata, pola interaksi yang terjadi cenderung berdasarkan adanya reward yang didapat dari pelaksanaan suatu program, umpan balik atasan-bawahan kurang berjalan, dan penyimpangan dalam komunikasi ke atas.

Berkaitan dengan kurangnya keterbukaan, salah satunya ditunjukkan dengan tidak adanya komunikasi terkait pelaksanaan kegiatan Tour de Flores kepada beberapa dinas terkait. Masalah yang muncul berkaitan dengan pola interaksi dalam komunikasi pemerintahan antar perangkat daerah di lingkup Pemerintah Provinsi NTT ditunjukkan dengan adanya konflik dan ambiguitas peranan pada pihak atasan yang memiliki korelasi dengan interaksi langsung di antara para bawahan. Hal ini ditunjukkan dalam perencanaan kegiatan atau program kerja terkait agenda pengembangan pariwisata. Di dalam persoalan feedback atau umpan balik atasan-bawahan, komunikasi pemerintahan antar perangkat daerah mengalami tantangan dalam kejelasan informasi yang disampaikan atasan terkait pengembangan agenda pariwisata. Sedangkan, masalah yang muncul berkaitan dengan penyimpangan dalam komunikasi ke atas adalah kurangnya kepercayaan antar para aparatur, atasan kepada bawahan dan bawahan yang cenderung mengabaikan komentar-komentar kritis dalam interaksi dengan atasan (Pace \& Faules, 2010).

Proses komunikasi horizontal berlangsung juga dalam komunikasi pemerintahan antar perangkat daerah dalam pengembangan pariwisata. Tipologi komunikasi horizontal dalam komunikasi internal yang berlangsung antar perangkat daerah dalam pengembangan pariwisata tergantung dari bagaimana proses komunikasi vertikalnya. Pace \& Faules (2010) menegaskan bahwa keberlangsungan komunikasi horizontal ditentukan oleh aliran informasi antara pelaku komunikasi dalam suatu organisasi. Hasil penelitian menunjukkan bahwa komunikasi horizontal antar perangkat daerah dalam pengembangan pariwisata berlangsung dalam iklim komunikasi yang kurang kondusif. Hal ini ditunjukkan dengan komunikasi yang kurang fleksibel, dan komunikasi yang terjadi tidak 
mengarah pada mutual understanding. Sedangkan, Pace \& Faules (2010) menggambarkan bahwa komunikasi horizontal yang kurang kondusif seringkali dihadapkan pada masalah persaingan dalam sumber daya, perhatian yang tinggi pada mobilitas ke atas dan kurangnya perhatian secara menyeluruh pada bawahan.

Komunikasi pemerintahan antara para birokrat yang memiliki jabatan yang sama dari setiap perangkat daerah merupakan bentuk komunikasi horizontal. Intensitas tipe komunikasi ini sangat diperlukan dalam menjembatani perbedaan prioritas program atau kegiatan masing-masing perangkat daerah. Komunikasi internal dalam komunikasi pemerintahan diperlukan dalam memperkuat perencanaan program atau kegiatan terkait pengembangan pariwisata. Oleh karena itu, komunikasi pemerintahan yang dijalankan ditekankan pada fungsi organisasi pemerintahan untuk managing staff. Komunikasi pemerintahan dengan maksud managing staff merupakan komunikasi internal organisasi yang bertujuan agar pegawai atau staf mengetahui dan memahami apa yang harus dikerjakan, bagaimana mengerjakan dan agar eksekutif pemerintah mendapatkan informasi dari pegawai tentang hasil pelaksanaan pekerjaan yang kesemuanya bermanfaat untuk mencapai tujuan-tujuan organisasi pemerintah secara efektif dan efisien (Silalahi, 2004).

Hasil penelitian tentang komunikasi pemerintahan antar perangkat daerah dalam pengembangan pariwisata di Provinsi NTT menegaskan pula bahwa komunikasi pemerintahan dengan arus informasi yang mengalir secara downward lebih dominan dan menjadi ciri khas komunikasi pemerintahan sentralistis. Komunikasi pemerintahan yang menekankan komunikasi downward, dari atasan kepada bawahan tampak dalam sistem birokrasi. Berbagai keputusan kebijakan dan program-program pembangunan telah ditetapkan oleh Kepala Daerah dan dilaksanakan oleh kalangan pejabat eselon II yang ditugaskan kepada para pejabat eselon III dan IV untuk melaksanakannya. Aparatur tidak dapat berkreatifitas dan berbuat banyak terhadap isi informasi yang disampaikan dari atas. Bahkan, informasi umpan balik yang diberikan oleh bawahan kepada atasan terbatas. Dominasi komunikasi downward yang sangat kental dalam sistem birokrasi mengakibatkan bawahan memiliki loyalitas yang tinggi kepada atasan sehingga bawahan lebih sering mengutamakan pelayanan kepada atasannya (Silalahi, 2004).

Misalnya, pada pelaksanaan rapat koordinasi pengembangan pariwisata lingkup Pemerintah Provinsi NTT, pola komunikasi downward yang dominan diganti dengan pola komunikasi upward yang cukup dominan dalam komunikasi pemerintahan antar perangkat daerah lingkup pemerintah provinsi NTT dan Kabupaten/Kota se-Provinsi NTT terkait pengembangan agenda pariwisata. Arus informasi baik dari sesama pimpinan maupun dari bawahan menciptakan iklim komunikasi pemerintahan yang kondusif. Meskipun demikian, keberlangsungan komunikasi tersebut tidak mengarah pada mutual understanding tentang kosensus bersama dalam pengembangan pariwisata. Hal ini disebabkan karena content (agenda) komunikasi pemerintahan terkait pariwisata ditempatkan pada pilihan pesan semata bukan ditempatkan pada penggerakkan pesan secara simultan dan terorganisir dalam bentuk aksi nyata. Hal lainnya yang ditemukan adalah derajat saling ketergantungan terhadap agenda komunikasi sebatas pada forum atau bentuk komunikasi yang dilaksanakan. Sedangkan dalam tindakan atau aksi nyata masih terdapat kesenjangan komunikasi.

Dalam pelaksanaan rapat koordinasi pengembangan pariwisata, komunikasi pemerintahan yang berlangsung mencerminkan komunikasi yang fleksibel. Feedback yang terjadi dalam komunikasi horizontal dan komunikasi dari bawah ke atas memberikan sumbangsih ide dan gagasan, informasi terkait pengembangan pariwisata di Provinsi NTT. Dalam hal ini, komunikasi yang fleksibel membuat bawahan aktif menyampaikan informasi ke atas (Silalahi, 2004; Harris, 2002).

Komunikasi ke atas dalam sebuah organisasi penting untuk dilaksanakan dengan beberapa alasan. Pertama, aliran informasi ke atas memberi informasi berharga untuk pembuatan keputusan. Kedua, komunikasi ke atas memberitahukan kepada pimpinan kapan 
bawahan siap menerima informasi dan seberapa baik bawahan menerima apa yang dikatakan. Ketiga, komunikasi ke atas memungkinkan adanya keterbukaan komunikasi dengan adanya keluhan yang muncul ke permukaan sehingga atasan tahu yang sedang menjadi persoalan dalam iklim komunikasi. Keempat, komunikasi ke atas menumbuhkan apresiasi dan loyalitas kepada organisasi dengan memberi kesempatan kepada bawahan untuk mengajukan pertanyaan dan menyumbang gagasan serta saran-saran mengenai organisasi. Kelima, komunikasi ke atas dapat memberikan pemahaman kepada atasan untuk memahami apa yang diharapkan dari aliran informasi ke bawah. Keenam, komunikasi ke atas membantu bawahan mengatasi masalah pekerjaan (Sharman; Machaver; Conboy; Planty \& Machaver dalam Pace \& Faules, 2010). Ketujuh, pimpinan yang lebih tinggi kedudukannya mendapatkan informasi yang diperlukan atas berbagai hal untuk menilai berbagai kekurangan, dan sebagai bahan pertimbangan dalam pengambilan keputusan, dan mungkin untuk memperbaiki komunikasi ke bawah, terutama melalui beberapa jenis feedback. Dalam kebanyakan organisasi, jika arus informasi ke atas kurang memadai akan mengakibatkan manajemen tingkat atas akan kurang mendapatkan informasi untuk mengetahui dan menyadari secara cepat dan tepat keadaan organisasi pada umumnya dan keadaan bawahan pada khususnya (Silalahi, 2004; Harris, 2002).

\section{Telaah Unsur-Unsur Komunikasi Organisasi dan Dimensi Hubungan dalam Komunikasi Pemerintahan antar Perangkat Daerah dalam Pengembangan Pariwisata di NTT}

Proses komunikasi pemerintahan antar perangkat daerah dalam pengembangan pariwisata di NTT juga melibatkan unsurunsur komunikasi yang menentukan keberlangsungan komunikasi berjalan secara efektif atau tidak. Hasil penelitian menunjukkan bahwa unsur-unsur komunikasi yang terlibat meliputi komunikator dan komunikan (para birokrat), pesan yang disampaikan terkait agenda pariwisata, penggunaan media komunikasi, seperti surat, dan handphone. Proses komunikasi yang terjadi memunculkan rendahnya efek komunikasi, sehingga berpengaruh terhadap feedback. Hal ini ditunjukkan dengan mandeknya komunikasi pemerintahan antar perangkat daerah dalam pengembangan pariwisata di Provinsi NTT setelah pelaksanaan rapat bersama.

Berkaitan dengan agenda komunikasi dalam pengembangan pariwisata, content pesan tidak dikemas ke dalam agenda masing-masing perangkat daerah. Oleh karena itu, pengembangan pariwisata mensyaratkan kualitas komunikasi pemerintahan yang menentukan agenda komunikasinya. Prioritas agenda pengembangan pariwisata disesuaikan dengan kebutuhan masing-masing perangkat daerah. Komunikasi pemerintahan berada dalam problematika ego sektoral. Ego sektoral terwujud dalam ego kebijakan komunikasi, dengan tidak mengembangkan suatu pola transparansi komunikasi dalam perencanaan lintas sektor, maka terjadi tumpang tindih dalam pelaksanaan program atau kegiatan oleh beberapa perangkat daerah di lingkup Pemerintah Provinsi NTT. Alasan yang dominan adalah penguatan pesan yang menekankan pada nilai urgensi, asas manfaat dan sebagainya masih ditentukan pada posisi atau jabatan yang lebih tinggi. Distribusi pesan masih bersumber dari kalangan atas sebagai decision maker dan memerlukan waktu yang relatif lama untuk sampai ke bawah. Oleh karena itu, realitas tersebut memengaruhi kredibilitas pesan dan transparansi pesan yang ditentukan dari legalitas komunikator. Padahal, dalam komunikasi pemerintahan disarankan agar arus penyampaian dan penerimaan pesan yang dilakukan lebih cenderung melalui jaringan dan hubungan informal (Perez, 2000).

Kontinuitas dari komunikasi pemerintahan yang berlangsung memiliki efek yang berbeda menurut source of message (komunikator). Efek dari pesan yang disampaikan lebih berorientasi source of message daripada content of message. Implikasinya, feedback yang diharapkan dari tujuan pelaksanaan komunikasi pemerintahan 
tidak berjalan optimal. Feedback berlangsung juga dalam konteks yang berbeda.

Kebijakan komunikasi terkait diseminasi informasi yang menjalankan fungsi perencanaan, kontrol, pengawasan, dan evaluasi terjadi dalam tingkatan komunikasi yang berbeda-beda. Masalahnya adalah agenda komunikasi (pengembangan pariwisata di Provinsi NTT) tidak didukung dengan efektivitas komunikasi pemerintahan dari aspek manajemen komunikasi pemerintahan, komunikasi politik, dan komunikasi pembangunan. Pesan mengalami distorsi, perubahan arti, maksud, dan tujuan di setiap tingkatan dalam sistem komunikasi. Pada level terendah, isi pesan seringkali tidak dilaksanakan. Problem lain yang ditemukan adalah pilihan media komunikasi pemerintahan yang digunakan. Hasil pengumpulan data masih menempatkan penggunaan surat formal sebagai media komunikasi yang utama dalam diseminasi informasi tentang berbagai kegiatan pengembangan pariwisata. Kelemahan dalam penggunaan media ini sebagai berikut; timing kecepatan informasi. Informasi yang sampai pada komunikan tidak dapat ditindaklanjuti karena kendala jadwal pelaksanaan kegiatan.

Gambaran komunikasi pemerintahan antar perangkat daerah di lingkup Pemerintah Provinsi NTT memberikan sebuah dasar pemikiran kritis tentang bagaimana menata komunikasi pemerintahan selanjutnya. Karl Weick dalam Littlejohn \& Foss (2009), menggarisbawahi kerangka filosofi komunikasi sebagai dasar dari kehidupan berorganisasi. Menurut Weick, organisasi terbentuk oleh aktivitas komunikasi. Organisasi itu sendiri merupakan sesuatu yang dicapai manusia melalui sebuah proses komunikasi yang berkelanjutan. Melalui aktivitas komunikasi dalam sebuah organisasi, segala bentuk ketidakpastian, kesulitan, ambiguitas, kurangnya keterbukaan, fenomena ego sektoral, dan beberapa masalah lainnya dengan tingkatan yang berbeda-beda dapat dibicarakan secara bersama-sama dan dicapai mutual understanding.

Di samping itu, komunikasi pemerintahan antar perangkat daerah dalam pengembangan pariwisata ditempatkan dalam sebuah jaringan komunikasi yang terstruktur, fleksibel dan patuh pada aturan-aturan organisasi yang mendasari jaringan formal tersebut (Littlejohn \& Foss, 2009). Untuk menyinergikan setiap program dan kegiatan dalam pengembangan pariwisata, komunikasi pemerintahan antar perangkat daerah diposisikan dalam sebuah jaringan formal yang dihasilkan bersama. Tentunya, unsurunsur komunikasi dalam jaringan komunikasi tersebut melibatkan semua perangkat daerah terkait dan diberi keleluasaan dalam membangun komunikasi.

Dari perspektif di atas, komunikasi pemerintahan yang terjadi antar perangkat daerah mengerucut pada dimensi relasional yang perlu dicermati. Komunikasi pemerintahan antar perangkat daerah di lingkup Pemerintah Provinsi NTT dalam pengembangan pariwisata berlangsung dalam berbagai bentuk relasi atau hubungan. Secara umum, hubungan yang menonjol dalam komunikasi pemerintahan adalah hubungan atasan-bawahan. Proses komunikasi yang berlangsung masih mengikuti urutan hierarki dalam lembaga pemerintah. Dalam konteks hubungan ini, aliran informasi antara para birokrat lingkungan Pemerintah Provinsi NTT seringkali menghadapi masalah kelambanan informasi, sehingga terjadi kelambanan dalam action program dan rendahnya keterlibatan sesama perangkat daerah karena kecenderungan terjadinya perubahan atau distorsi pesan pada saat komunikasi.

Bentuk relasi atau hubungan lain yang ditunjukkan dalam komunikasi pemerintahan antar perangkat daerah lingkup Pemerintah Provinsi NTT adalah hubungan posisional. Kaitan dengan hubungan ini, hasil penelitian menunjukkan bahwa komunikasi pemerintahan seringkali mengabaikan struktur otoritas dan tugas-tugas fungsional anggota suatu institusi dalam perencanaan program atau kegiatan yang berkaitan dengan pengembangan pariwisata. Posisi Bappeda Provinsi NTT yang memiliki otoritas dalam menjembatani atau memediasi keberlangsungan komunikasi pemerintahan antar perangkat daerah terkait perencanaan program atau kegiatan pengembangan pariwisata di NTT kurang berjalan masksimal. Selain itu, dengan adanya 
hubungan posisional, bentuk komunikasi pemerintahan yang terjadi di luar dari sistem atau pola yang berlaku. Pilihan bentuk komunikasi pemerintahan yang digunakan juga tidak sesuai dengan agenda utama komunikasi.

\section{PENUTUP}

\section{Simpulan}

Komunikasi pemerintahan antar perangkat daerah di lingkungan pemerintah Provinsi NTT terkait pengembangan pariwisata mengalami berbagai problem yang berkaitan dengan tipe-tipe komunikasi, unsurunsur komunikasi, dan dimensi hubungan dalam komunikasi organisasi.

Berbagai masalah tipologi komunikasi pemerintahan lebih dominan terjadi dalam komunikasi dari atas ke bawah. Hal ini disebabkan karena sistem komunikasi pemerintahan dalam sistem birokrasi mencirikan komunikasi yang kaku (rigid), kelambanan berkomunikasi karena aliran informasi secara berjenjang atau hierarki dan komunikasi yang kurang transparan dan akuntabel.

Selain itu, dari perspektif dimensi relasi dalam komunikasi pemerintahan, proses komunikasi yang berlangsung lebih menonjolkan dimensi relasi atasan-bawahan dan relasi posisional.

\section{Saran}

Pilihan tipe komunikasi pemerintahan yang digunakan perlu memerhatikan semua unsur komunikasi secara efektif dan efisien dan sebaiknya ditempatkan dalam konteks komunikasi yang fleksibel serta memperhatikan aspek transparansi. Aktivitas komunikasi seperti ini perlu ditingkatkan dan pada waktu tertentu digunakan pula pendekatan komunikasi informal dengan tetap mengikuti aturan yang berlaku.

\begin{tabular}{llr}
\multicolumn{1}{c}{ Proses komunikasi pemerintahan } \\
sebaiknya mencermati & dan \\
mempertimbangkan pula dimensi & relasi \\
atasan-bawahan dan posisional & untuk \\
program-program & pembangunan & yang \\
diprioritaskan. & & \\
&
\end{tabular}

Untuk mengoptimalkan komunikasi pemerintahan antar perangkat daerah dalam pengembangan pariwisata di Provinsi NTT, diperlukan suatu model jaringan komunikasi pemerintahan yang efektif dan efisien, penguatan persepsi dan pemahaman pesan secara bersama-sama dari level pimpinan (pimpinan pratama) dan penguatan peran Bappeda sebagai penghubung untuk menciptakan sinergitas dalam perencanaan, sehingga dapat menghilangkan ego sektoral dalam pelaksanaannya di lapangan.

\section{DAFTAR PUSTAKA}

Akmal, A. (2006) Koordinasi Antar Instansi Terkait dalam Pelaksanaan Pembangunan di Daerah. Jurnal Demokrasi. [Online] 5 (1). Available from: http://ejournal.unp.ac.id/index.php/jd/article/ view/1066.

Bappeda Provinsi NTT (2017) Rencana Kerja Bappeda Provinsi NTT.

Bokau, I.N. (2013) Peranan Komunikasi Pemerintahan dalam Meningkatkan Pembangunan di Desa Boyong Atas (Suatu Studi Peranan Kepala Desa). Jurnal Acta Diurna. [Online] 2 (3). Available from: https://ejournal.unsrat.ac.id/index.php/actadi urna/article/view/1916.

Buluamang, Y.M.O. (2017) Transparansi Komunikasi Dalam Birokrasi Pemerintahan. Jurnal Penelitian Pers dan Komunikasi Pembangunan. [Online] 21 (1), 49-57. Available from: http://jurnalp2kp.id/index.php/jp2kp/article/view/63.

Bungin, B. (2007) Metode Penelitian Kualitatif. Jakarta, Kencana Prenada Media.

Djese, S.T. (2013) Strategi Pengembangan Objek Wisata Komodi di Kabupaten Manggarai Barat Terhadap Usaha Peningkatan Jumlah Kunjungan Wisatawan di Nusa Tenggara Timur.

Febrian, R.A. (2015) Analisis Permasalahan Koordinasi Pemerintahan (Tinjauan Konseptual dan Teortis). Jurnal Kajian Pemerintahan, Politik dan Birokrasi WEDANA. [Online] 1 (1), 41-51. Available from:

http://jurnal.uir.ac.id/index.php/WDN/article /view/426.

Harris, T.E. (2002) Applied Organizational Communication: Principles and Pragmatics for Future Practice. London, Lawrence 
Erlbaum Associates.

Hasan, E. (2007) Komunikasi Pemerintahan. Bandung, Refika Aditama.

Littlejohn, S.W. \& Foss, K.A. (2009) Teori Komunikasi. Jakarta, Salemba Humanika.

Lubis, E.E. (2012) Hambatan-Hambatan Komunikasi Kepemimpinan Regional di Pemerintahan. Jurnal Komunikasi. 1 (1).

Moeleong, L.J. (2009) Metode Penelitian Kualitatif. Bandung, Remaja Rosdakarya.

Nirwandar, S. (2006) Pengembangan Sektor Pariwisata di Era Otonomi Daerah,. [Online]. 2006. Available from: http://www.kemenpar.go.id/asp/detil.asp?c= 22\&id=1030 [Accessed: 20 May 2017].

Nugraha, M.T. (2015) Model Pengembangan Pariwisata Berbasis Masyarakat di Provinsi Nusa Tenggara Timur.

Pace, R.W. \& Faules, D.F. (2010) Komunikasi Organisasi: Strategi Meningkatkan Kinerja Perusahaan. Deddy Mulyana (ed.). Bandung, Remaja Rosdakarya.

Perez, M.A. (2000) The effects of information flow, seniority and status on communication satisfaction within a United States federal bureaucracy. [Online]. University of Oklahoma. Available from: https://hdl.handle.net/11244/6050.

Ruijer, H.J.M. (2013) Proactive Transparency and Government Communication in the USA and the Netherlands. [Online]. Virginia Commonwealth University. Available from: https://scholarscompass.vcu.edu/etd/3233.

Salim, A. (2011) Potensi dan Strategi Pengembangan Sektor Pariwisata Sebagai Lokomatif Pembangungan Ekonomi Daerah Nusa Tenggara Timur.

Setyowati, R.M. (2016) Strategi Komunikasi Yang Mendukung Perkembangan Pariwisata Berbasis Ekonomi Kerakyatan. Jurnal The Messenger. [Online] 2 (2), 11. Available from: doi:10.26623/themessenger.v2i2.298.

Siagian, S.P. (2010) Administrasi Pembangunan: Konsep, Dimensi dan Strateginya. Jakarta, Bumi Aksara.

Silalahi, U. (2004) Komunikasi Pemerintahan: Mengirim dan Menerima Informasi Tugas dan Informasi Publik. Jurnal Administrasi Publik. [Online] 3 (1), 36-54. Available from:

http://journal.unpar.ac.id/index.php/JAP/arti cle/view/652.

Susanto, E.H. (2017) Kelambanan Reformasi Birokrasi dan Pola Komunikasi Lembaga Pemerintah. Jurnal ASPIKOM. [Online] 1 (1), 109 . Available from: doi:10.24329/aspikom.v1i1.11.

Widhiastuti, H. (2013) The Effectiveness of Communications in Hierarchical Organizational Structure. International Journal of Social Science and Humanity. [Online] 2 (3), 185-190. Available from: doi:10.7763/IJSSH.2012.V2.93. 